Contents Vol. 8, 1989

\title{
Neuroepidemiology
}

Edited by B.S. Schoenberg from 1982 to 1983

Editor-in-Chief

F. Clifford Rose, London

Deputy Editor

M. Alter, Philadelphia, Pa.

Editorial Board

L. Amaducci, Firenze

R. Boeri, Milano

C.L. Bolis, Geneve

P.M. Dalai, Bombay

J.-P. Dartigues, Bordeaux

G. Dean, Dublin

C. Gajdusek, Bethesda, Md.

W.M. Garraway, Edinburgh

M. Goldstein, Bethesda, Md.

K. Kondo, Sapporo

J.F. Kurtzke, Washington, D.C.

L. Olivares, Mexico City

B.O. Osuntokun, Ibadan

A. Portera-Sanchez, Madrid

S. Refsum, Oslo

B.P.M. Schulte, Nijmegen

F.J. Stanley, Perth

M. Susser, New York, N.Y.

P.A. Wolf, Boston, Mass.

D. Ziegler, Kansas City, Kans. 


\section{Contents Vol. 8,1989}

No. $1 \quad$ Original Papers

Declining Trends in Mortality from Cerebrovascular Disease at Ages 10-65 Years: A Test of Validity

Garland, F.C.; Lilienfeld, A.M.; Garland, C.F......

Conditions Associated at Death with Specific Types of Completed Stroke in Patients with and without Hypertension: A Case-Control Study

Ogunniyi, A.; Chandra, V.; Schoenberg, B.S

Creutzfeldt-Jakob Disease in Japan: An Epidemiological Study Done in a Selected PrefeSafl

ture between 1976 and 1986

Akai, J.; Ishihara, O.; Higuchi, S.

Risk of Multiple Sclerosis in Relation to Industrial Activities: An Ecological Study in Four

European Countries

Lauer, K.

Prevalence of Neurological Diseases in Madrid, Spain

Cruz Gutierrez-del-Olmo A., M.; Schoenberg, B.S.; Portera-Sanctiez, A

Descriptive Epidemiologic Survey of Head Injury in the Army: 1983 Hospitalized Cases

McCarroll, J.E.; Zych, K.A.

No. 2 Editorial

New International Headache Classification

Olesen, $\mathrm{J}$

-Original Papers

World-Wide Trends in Multiple Sclerosis Mortality

Lai, S.-M.; Zhang, Z.-X.; Alter, M.; Sobel, E.

Secular Trends in Mortality Rates from Motor Neuron Disease in Kentucky 1964-1984

Stallones, L.; Kasarskis, E.J.; Stipanowich, C; Snider, G.

Epidemiology of Motor Neuron Disease in Two Italian Provinces. Analysis of Secular

Trend and Geographic Distribution

Chi6, A.; Brignolio, F.; Meineri, P.; Rosso, M.G.; Schiffer, D

Transient Ischemic Attacks in the Community: Occurrence and Clinical Characteristics.

A Population Survey in the Area of Florence, Italy

Fratiglioni, L.; Arfaioli, C; Nencini, P.; Ginanneschi, A.; Iaquinta, L.; Marchi, M.;

Inzitari, D

Stroke in a French Prospective Population Study

Giroud, M.; Beuriat, P.; Vion, P.; D'Athis, P.H.; Dusserre, L.; Dumas, R

Epidemiology of Huntington's Disease in Rijeka District, Yugoslavia

Sepci6, J.; Antonelli, L.; Sepic-Grahovac, D.; Maferljan, E

No. 3 Original Papers

Neuroepidemiology of Human T-Lymphotrophic Virus Type-I-Associated Tropical Spastic

Paraparesis

Molgaard, C.A.; Eisenman, P.A.; Ryden, L.A.; Golbeck, A.L.

Prevalence of HTLV-I-Associated Myelopathy among HTLV-I Carriers in Saga, Japan

Shibasaki, H.; Tokudome, S.; Kuroda, Y.; Yanagawa, T.; Yoshihara, M

Epidemiologic Study on the Association between Body Burden Mercury Level and Idiopathic Parkinsonls Disease

Ngim, C.-H.; Devathasan, G. 
Amyotrophic Lateral Sclerosis Severity Scale

Hillel, A.D.; Miller, R.M.; Yorkston, K.; McDonald, E.; Norris, F.H.; Konikow, N. . 142 Incidence and Prevalence of Motor Neuron Disease in Two Danish Counties

H0jer-Pedersen, E.; Christensen, P.B.; Jensen, N.B

Strokes in the Young Population in West-Central India - Some Observations on Changing

Trends in Morbidity and Mortality

Dalai, P.M.; Dalai, K.P.; Vyas, A.C

No. $4 \quad$ Original Papers

Inheritance of Alzheimer's Disease: Epidemiologic Evidence

Chandra, V.; Schoenberg, B.S

Serum Cholesterol, Its Lipoprotein Fractions among Survivors of Cerebrovascular Disease.

A Case-Control Study

Wang, K.; Schoenberg, B.S.; Ouyang, S.; Wang, C; Cheng, X.; Li, S.; Bolis, C.L. ... 175 Cerebral Palsy in TciTOri, Japan. Benefits and Risks of Progress in Perinatal Medicine

Takeshita, K.; Ando, Y; Ohtani, K.; Takashima, S...

Patterns of Mortality from Hereditary Ataxias in the United States, 1971 and 1973-1978

Leone, M.; Chandra, V.; Schoenberg, B.S

Dietary Changes in Temporal Relation to Multiple Sclerosis in the Faroe Islands: An Evaluation of Literary Sources

Lauer, K.

Increasing Incidence of Multiple Sclerosis in South Lower Saxony, Germany

Poser, S.; Stickel, B.; Krtsch, U.; Burckhardt, D.; Nordman, B.

Neuroepidemiological Survey on Sicilian Population. A Feasibility Study

Morgante, L.; Grigoletto, F.; Meneghini, F.; Vita, G.; Coraci, M.A.; Di Rosa, A.E.;

Bolis, C.L.; Di Perri, R

No. $5 \quad$ Original Papers

National General Practice Study of Epilepsy and Epileptic Seizu^^${ }^{\wedge}$

Objectives and Study Methodology of the Largest Reported Prospective Cohort Study

of Epilepsy

National General Practice Study of Epilepsy and Epileptic Seizures

Reliability of Seizure Diaries in Adult Epileptic Patients

Neugebauer, R

Etiology and Patterns of Seizures in the Elderly

Sundaram, M.B.M

On the Estimation of the Distribution of the Latent Period of Multiple Sclerosis

Wolfson, C; Wolfson, D.B.; Zielinski, J.M

Multiple Sclerosis: Disability and Mortality in a Cohort of Clinically Diagnosed Patients

Citterio, A.; Azan, G.; Bergamaschi, R.; Erbetta, A.; Cosi, V

Routine Blood Chemistry Screen: A Diagnostic Aid for Alzheimer's Disease

Kasa, M.; Bierma, T.J.; Waterstraat, F., Jr.; Corsaut, M.; Singh, S.P

Evidence for Seasonal Variation in Polymyositis

Manta, P.; Kalfakis, N.; Vassilopoulos, D

Risk Factors for Tumors of the Brain and Cranial Meninges in Seventh-Day Adventists

Mills, P.K.; Preston-Martin, S.; Annegers, J.F.; Beeson, W.L.; Phillips, R.L.; Fraser, G.E. 266

Book Reviews

No. 6

Original Papers

Pre-Morbid Height and Weight as Risk Factors for Development of Central Nervous System Neoplasms

Helseth, A.; Tretli, S

Descriptive Epidemiology of Primary Tumors of the Brain, Cranial Nerves and Cranial

Meninges in Los Angeles County

Preston-Martin, S.

Incidence and Risk Factors of Parkinson's Disease in The Netherlands

Multifactorial Inheritance and Recurrence Risks of Multiple Sclerosis in Italian Patients

Grasso, M.G.; Frontali, M.; Bernardi, S.; Pantano, P.; Fieschi, C. 
Multiple Sclerosis in Relation to Meat Preservation in France and Switzerland

Lauer, K

Neurotraumatological Survey in Northern Israel. I. Annual and Seasonal Variations

Levi, L.; Linn, S.; Feinsod, M.; Revach, M ...

Author Index

Subject Index

S. Karger $\bullet$ Medical and Scientific Publishers

Basel $\bullet$ Miinchen $\square$ Paris $\bullet$ London $\bullet$ New York $\bullet$ New Delhi $\bullet$ Bangkok $\square$ Singapore $\bullet$ Tokyo $\bullet$ Sydney

Drug Dosage

All rights reserved

The authors and the publisher have exerted every effortNo part of this publication may be translated into otherto ensure that drug selection and dosage set forth regulations, age and retrieval system, without permission in writingand the constant flow of information relating to drug from the publisher or, in the case o when the recom-

$\mathrm{m}$. mended agent is a new and/or infrequently employed

S. Karger AG

P.O. Box

CH-4009 Basel (Switzerland)

drug. Printed in Switzerland by Thiir AG Offsetdruck

Pratteln 